\title{
Correction to: Patient-Specific Mandibular Reconstruction Plates Increase Accuracy and Long-Term Stability in Immediate Alloplastic Reconstruction of Segmental Mandibular Defects
}

\author{
A. N. Zeller ${ }^{1}$ (D) M. T. Neuhaus ${ }^{1} \cdot$ L. V. M. Weissbach ${ }^{1} \cdot$ M. Rana ${ }^{2} \cdot$ \\ A. Dhawan ${ }^{3}$ - F. M. Eckstein ${ }^{1}$ - N. C. Gellrich ${ }^{1}$ R. M. Zimmerer ${ }^{1}$
}

Accepted: 8 April 2021/Published online: 23 April 2021

(C) The Author(s) 2021

Correction to: J. Maxillofac. Oral Surg. (Oct-Dec 2020) 19(4):609-615 https://doi.org/10.1007/s12663-019-01323-9

The article "Patient-Specific Mandibular Reconstruction Plates Increase Accuracy and Long-Term Stability in Immediate Alloplastic Reconstruction of Segmental Mandibular Defects" written by A. N. Zeller, M. T. Neuhaus, L. V. M. Weissbach, M. Rana, A. Dhawan, F. M. Eckstein, N. C. Gellrich, R. M. Zimmerer originally published electronically on the publisher's internet portal (currently SpringerLink) on 3 January 2020 without open access. After publication in volume 19, issue 4, page 609-615 the author decided to opt for Open Choice and to make the article an Open Access publication. Therefore, the copyright of the article has been changed to (C) The Author(s) 2020 and the article is forthwith distributed under the terms of the Creative Commons Attribution 4.0 International Licence, which permits use, sharing, adaptation, distribution and reproduction in any medium or format, as long as you give appropriate credit to the original author(s) and the source, provide a link to the Creative Commons licence, and indicate if changes were made. The images or other third-party material in this article are included in the article's Creative Commons licence, unless indicated otherwise in a credit line to the material. If material is not included in the article's Creative Commons licence and your intended use is not permitted by statutory regulation or exceeds the permitted use, you will need to obtain permission directly from the copyright holder. To view a copy of this licence, visit http://creativecommons. org/licenses/by/4.0/.

The original article has been updated.

The original article can be found online at https:// doi.org/10.1007/s12663-019-01323-9.

A. N. Zeller

Zeller.Alexander@mh-hannover.de

1 Department of Oral and Maxillofacial Surgery, Hannover Medical School, Hannover, Germany

2 Department of Oral and Maxillofacial Surgery, University Hospital Duesseldorf, Düsseldorf, Germany

3 Sri Guru Ram Das Institute of Dental Sciences and Research, Amritsar, India 